\title{
IMPLEMENTASI E-MODUL PENGAYAAN ISOLASI DAN KARAKTERISASI BAKTERI DALAM MENINGKATKAN KEMANDIRIAN BELAJAR SISWA SMA
}

\author{
Dyah Aniza Kismiati ${ }^{1}$ \\ ${ }^{1}$ Program Studi Pendidikan Biologi, Program Pascasarjana UNY, Jalan Colombo \\ No. 1, Yogyakarta \\ E-mail : anizady93@gmail.com
}

\begin{abstract}
This study aims to determine the effect of the use of enrichment e-modules in increasing the learning independence of high school students. This research is a quasi experimental study with nonequivalent pretest posttest control group design. The sample of the study is Jetis 1 High School students Bantul consisting of 2 classes. This sample was taken based on purposive sampling technique, class X MIPA 5 as a control class and class X MIPA 1 as an experimental class. The instruments used were questionnaires and observation sheets for students' learning independence. Data were analyzed through Independent Sample T-Test and Normalized Gain Score (NGain Score). The results showed that the enrichment E-module that was developed had a significant effect with a significance value of $0,000<0.005$ and the increase was categorized as moderate with the results of the calculation of the N-Gain Score of 0.307
\end{abstract}

Keywords : e-modul, enhancement, bacteria, implementation, self regulation learning

\begin{abstract}
Abstrak: Penelitian ini bertujuan untuk mengetahui pengaruh implementasi $e$-modul pengayaan dalam meningkatkan kemandirian belajar siswa SMA. Penelitian ini merupakan penelitian quasi eksperimen dengan desain nonequivalent pretest posttest control group. Sampel penelitian yaitu siswa SMA N 1 Jetis Bantul yang terdiri atas 2 kelas. Sampel ini diambil berdasarkan teknik purposive sampling, kelas X MIPA 5 sebagai kelas kontrol dan kelas X MIPA 1 sebagai kelas eksperimen. Instrumen yang digunakan berupa angket dan lembar observasi kemandirian belajar siswa. Data dianalisis melalui Independent Sample T-Test dan Normalized Gain Score (N-Gain Score). Hasil penelitian menunjukkan bahwa E-modul pengayaan yang dikembangkan berpengaruh secara signifikan dengan nilai signifikansi $0,000<0,005$ dan peningkatannya terkategori sedang dengan hasil penghitungan $N$-Gain Score sebesar 0.307 .
\end{abstract}

Kata kunci: E-modul, pengayaan, bakteri, kemandirian belajar.

Pembelajaran diartikan sebagai proses interaksi peserta didik dengan pendidik dan sumber belajar pada suatu lingkungan belajar (Depdiknas, 2003). Selama pembelajaran berlangsung, dilakukan pula evaluasi baik secara formatif maupun sumatif untuk mengetahui kemajuan proses belajar siswa. Dari hasil evaluasi tersebut, akan menempatkan siswa ke dalam kelompok atas dan bawah yang masing-masing diantaranya memerlukan tindak lanjut. Siswa yang berada dalam kelompok bawah diberikan penanganan berupa pemberian program remedial, sedangkan siswa yang berada di kelompok atas, yaitu dengan nilai diatas KKM akan diberikan tindak lanjut berupa pemberian program pengayaan.

Program pengayaan adalah program pendalaman materi pembelajaran yang diperuntukkan bagi siswa yang telah melampaui nilai Kriteria Ketuntasan Minimal (KKM). 
Berbeda dengan program remedial, pada program pengayaan menekankan pada penguatan aspek kompetensi yang sudah dikuasai siswa (Subali, 2016: 168). Program pengayaan dapat dilaksanakan melalui pembelajaran kelompok, pembelajaran mandiri, maupun pembelajaran berbasis tema (Direktorat Pembinaan SMA, 2017: 63-64). Pemilihan program pengayaan tersebut disesuaikan dengan karakteristik dan kebutuhan siswa.

Hasil wawancara dan observasi yang dilakukan di sebuah di SMA negeri di Kabupaten Bantul, mengungkap fakta bahwa program pengayaan yang dilakukan oleh guru biologi kelas $\mathrm{X}$ berupa program pengayaan belajar mandiri. Belajar mandiri adalah jenis program pengayaan dimana siswa yang telah mencapai penguasaan $100 \%$ ataupun siswa yang telah melampaui nilai KKM namun belum mencapai penguasaan $100 \%$ menjadi tutor bagi sesamanya (tutor sebaya). Namun karena adanya keterbatasan waktu, program pengayaan ini hanya dilakukan sesekali dan berupa pemberian tugas yakni latihan mengerjakan soal-soal dengan materi yang lebih mendalam yang belum disampaikan guru pada pembelajaran umum di kelas.

Sebenarnya, pengayaan secara mandiri dapat dilakukan dengan memanfaatkan sumber belajar. Namun sayangnya, sumber belajar untuk program pengayaan terutama pada mata pelajaran biologi masih terbatas. Apalagi yang terkait dengan materi bakteri pada Kompetensi Dasar (KD) 3.5. Hasil observasi dan wawancara dengan guru biologi yang mengajar di kelas $\mathrm{X}$ menunjukkan bahwa kemandirian belajar siswa masih rendah terutama terkait dengan referensi sumber belajar, dimana para siswa masih ketergantungan dengan sumber belajar yang berasal dari guru. Padahal, dari hasil wawancara yang dilakukan kepada beberapa orang siswa SMA, mereka memiliki ketertarikan terhadap materi bakteri.. Terlebih lagi jika materi disampaikan dalam bentuk elektronik yang menarik dan dapat diakses kapanpun dan dimanapun. Oleh karena itu, sumber belajar mandiri untuk program pengayaan materi bakteri di SMA sangat dibutuhkan.

Sumber belajar elektronik seperti E-modul dapat disusun berdasarkan hasil penelitian yang telah dilakukan. Penggunaan hasil penelitian sebagai dasar dari penyusunan sebuah sumber belajar (research based learning) akan memperkaya materi dan sajian fakta yang lebih nyata bagi siswa, sehingga diharapkan akan dapat meningkatkan hasil belajar dan kemandirian belajar siswa.

Hasil belajar dikatakan berhasil bila pembelajaran tersebut dianggap bermakna bagi siswa. Pembelajaran bermakna (meaningfull learning) seperti yang diungkapkan oleh Ausubel (Burhanuddin, 1996: 116) merupakan proses mengaitkan informasi atau materi baru dengan konsep-konsep yang telah ada dalam struktur kognitif. Pembelajaran akan lebih bermakna 
apabila tema yang dibahas adalah sebuah isu yang terkait dengan siswa, salah satu diantaranya adalah isu penggunaan probiotik sebagai campuran kosmetik remaja putri seperti masker wajah dan krim yang mengandung yogurt.

Yoghurt merupakan produk fermentasi yang berasal dari bakteri Lactobacillus bulgaricus. Bakteri ini merupakan salah satu jenis bakteri asam laktat. Selain bermanfaat dalam pembuatan produk fermentasi, bakteri asam laktat juga memiliki banyak keuntungan bagi manusia, terlebih sebagai bakteri probiotik. Berkaitan dengan isu bakteri probiotik, terdapat penelitian berkenaan dengan Isolasi, Seleksi, dan Karakterisasi Bakteri Asam Laktat dari Intestinum Itik Manila Sebagai Kandidat Probiotik oleh Puput Saputri yang dilakukan pada tahun 2018. Hasil penelitian ini dapat dijadikan sebagai sumber belajar yang menarik bagi siswa dan juga cocok digunakan untuk memperdalam materi bakteri pada KD 3.5 pada program pengayaan mengingat penjabaran sub materi terkait inokulasi dan pengecatan gram masih sangat minim diberikan pada saat pembelajaran reguler di kelas.

Penggunaan sumber belajar tidak hanya bertujuan untuk meningkatkan hasil belajar siswa terutama untuk ranah kognitif, melainkan juga bertujuan untuk megembangkan ranah sikap dan keterampilan. Sumber belajar memiliki banyak jenis yang dapat dipilih oleh guru sesuai dengan fungsi penggunaannya. Oleh karena bertujuan untuk memperkaya atau menambah materi (pengayaan) maka jenis sumber belajar yang sesuai untuk digunakan adalah modul sebab modul memiliki karakteristik self instructional, self contained, adaptive, stand alone dan user friendly (Daryanto, 2013: 9-11). Terlebih lagi dengan kemajuan ilmu dan teknologi pada saat ini, modul tidak hanya tersaji dalam bentuk cetak melainkan dapat tersaji dalam bentuk elektronik dengan didukung adanya penayangan video terkait materi, animasi, gambar, soal latihan dan glosarium, sehingga siswa akan lebih tertarik dan mudah untuk mengaksesnya kapanpun dan dimanapun. Dengan demikian, siswa tidak hanya bertambah pengetahuannya tetapi kemandirian belajarnya pun akan meningkat. Dari uraian tersebut maka penulis berinisiatif untuk melakukan kajian dan penelitian terkait pengaruh penggunaan e-modul pengayaan isolasi dan karakterisasi bakteri terhadap kemandirian belajar siswa.

\section{METODE}

Penelitian ini dilakukan di SMA Negeri 1 Jetis, Bantul, Yogyakarta pada semester ganjil tahun ajaran 2017/2018. Jenis penelitian ini adalah Quasi Experiment. Subjek penelitian yang digunakan sebanyak dua kelas (X MIPA 1 dan X MIPA 2) yang diambil melalui teknik pengambilan sampel bersyarat (purposive sampling) dengan pertimbangan bahwa siswa-siswi pada kedua kelas tersebut telah melampaui nilai KKM pada materi eubacteria atau kingdom 
monera yang ditetapkan oleh guru yakni sebesar 75 .

Variabel bebas dalam penelitian ini adalah.penggunaan e-modul pengayaan isolasi dan karakterisasi bakteri, sedangkan variabel terikat yaitu kemandirian belajar siswa. Instrumen yang digunakan untuk mengetahui kemandirian siswa sebelum dan selama menggunakan $E$ modul ini berupa lembar angket kemandirian belajar dan lembar observasi kemandirian belajar.

Angket kemandirian menggunakan skala Likert dengan lima alternatif pilihan yaitu TP (tidak pernah), J (jarang), K (kadang-kadang), SR (sering) dan SL (selalu). Lembar angket dan lembar observasi (yang diisi oleh peer reviewer) kemandirian belajar mengacu pada 4 aspek kemandirian, yaitu aspek inisiatif, bertanggungjawab, motivasi, dan responsif.

Data dari angket berskala likert ini diubah menjadi data kuantitatif sesuai Tabel 1.

Tabel 1. Konversi Penilaian Skala Likert dalam Skor

\begin{tabular}{lc}
\hline \multicolumn{1}{c}{ Penilaian } & Skor \\
\hline Sangat Baik (SB) & 5 \\
\hline Baik (B) & 4 \\
\hline Cukup (C) & 3 \\
\hline Kurang (K) & 2 \\
\hline Sangat Kurang (SK) & 1 \\
\hline
\end{tabular}

Penghitungan skor rata-rata dari setiap aspek yang dinilai dilakukan dengan rumus:

$$
\mathbf{X}=\mathbf{x} / \mathbf{n}
$$

Keterangan :

$\mathrm{X}=$ skor rata-rata;

$\mathrm{x}=$ jumlah skor;

$\mathrm{n}=$ jumlah reviewer/responden

Selanjutnya konversi skor rata-rata ke nilai 100 dengan cara:

$$
\text { Nilai tiap aspek }=\frac{\text { Skor rata-rata }}{\text { skor yang diharapkan }} \times 100
$$

Untuk mengetahui adanya peningkatan kemandirian belajar siswa dengan menggunakan e-modul, maka dilakukan uji Independent Sample T Test dengan mempertimbangkan syarat 
normalisasi dan homogenitas data. Adapun hipotesis yang digunakan dalam pengujian ini adalah:

$\mathrm{H}_{0}$ : Tidak ada perbedaan yang signifikan antara nilai rata rata kemandirian belajar siswa yang menggunakan E-modul pengayaan dengan yang tidak menggunakan E-modul pengayaan.

Ha : Ada perbedaan yang signifikan antara nilai rata rata kemandirian belajar siswa yang menggunakan E-modul pengayaan dengan yang tidak menggunakan $E$ modul pengayaan.

Analisis Independent Sample T-Test menggunakan bantuan program SPSS versi 16.0, sedangkan untuk mengetahui kategori peningkatan kemandirian belajar siswa maka dilakukan adaptasi penghitungan skor pencapaian ternormalisasi (normalized gain score). Rumus gain score ternormalisasi yaitu:

$$
\mathrm{g}=\frac{\text { skor posttest }- \text { skor pretest }}{\text { skor maksimum }- \text { skor } \text { pretest }}
$$

Dalam hal ini, skor posttest adalah nilai kemandirian belajar siswa setelah menggunakan E-modul pengayaan isolasi dan karakterisasi bakteri, sedangkan skor pretest adalah nilai kemandirian belajar siswa sebelum menggunakan E-modul pengayaan isolasi dan karakterisasi bakteri.

Hasil rerata nilai (g), digunakan untuk mengetahui kategori peningkatan kemandirian dan hasil belajar siswa dalam penggunaan E-modul pengayaan berdasarkan kategori gainscore ternormalisasi menurut Hake (1999) disajikan pada Tabel 2.

Tabel 2. Kategori $N$-gain score

\begin{tabular}{ll}
\hline Nilai gain score ternormalisasi & Kategori \\
\hline $\mathrm{g}>0,70$ & Tinggi \\
\hline $0,70>\mathrm{g}>0,30$ & Sedang \\
\hline $0,30>\mathrm{g}$ & Rendah \\
\hline
\end{tabular}

\section{HASIL}

Salah satu tujuan pengembangan E-modul pengayaan ini adalah untuk meningkatkan kemandirian belajar siswa dalam program pengayaan secara mandiri. Dengan menggunakan E-modul pengayaan ini diharapkan siswa dapat memperdalam pengetahuannya mengenai kingdom monera khususnya bakteri tanpa harus bergantung dari guru ataupun orang lain. Pen- 
ingkatan kemandirian belajar siswa pada kelas kontrol dan eksperimen dapat diketahui berdasarkan hasil analisis Independent Sample T-Test yang disajikan dalam Tabel 3.

Tabel 3. Hasil Penghitungan Independent Sample T-Test Data Kemandirian Belajar

\begin{tabular}{|c|c|c|c|c|c|}
\hline & & \multicolumn{3}{|c|}{ t-test for equality of means } & \multirow[t]{2}{*}{ keterangan } \\
\hline & & $\mathrm{T}$ & Df & Sig (2 tailed) & \\
\hline \multirow[t]{2}{*}{ Nilai } & Equal variances assumed & $-7,670$ & 52 & 0,000 & $\mathrm{H}_{0}$ ditolak \\
\hline & Equal variances not assumed & $-7,622$ & 49,121 & & \\
\hline
\end{tabular}

Hasil analisis pada Tabel 3 menunjukkan nilai sig (2-tailed) untuk kemandirian belajar siswa adalah $=0,000$. Karena sig (2-tailed) $<0,05$ yaitu $0,000<0,05$ maka $\mathrm{H}_{0}$ ditolak. Dengan demikian dapat disimpulkan bahwa ada perbedaan yang signifikan terhadap kemandirian belajar siswa antara kelas eksperimen dengan kelas kontrol. Kategori peningkatan kemandirian belajar melalui analisis Normalized Gain Score (N-gain score) ditunjukkan dalam Tabel 4 dan Tabel 5.

Tabel 4. N-Gain Score Peningkatan Kemandirian Belajar Siswa pada Kelas Kontrol

\begin{tabular}{|c|c|c|c|c|}
\hline Nilai & $\begin{array}{l}\text { Nilai Kemandirian } \\
\text { Pembelajaran }\end{array}$ & Sebelum & $\begin{array}{l}\text { Nilai Kemandirian } \\
\text { Pembelajaran }\end{array}$ & Selama \\
\hline Nilai Terendah & 56,67 & & 65,33 & \\
\hline Nilai Tertinggi & 72,67 & & 80 & \\
\hline Rata-rata Nilai & 71,72 & & 72,67 & \\
\hline Rata-rata Gain Score & \multicolumn{4}{|c|}{0,004} \\
\hline Kategori Gain Score & \multicolumn{4}{|c|}{ Rendah } \\
\hline
\end{tabular}

Tabel 5. N-Gain Score Peningkatan Kemandirian Belajar Siswa pada Kelas Eksperimen

\begin{tabular}{llll}
\hline Nilai & $\begin{array}{l}\text { Nilai Kemandirian Sebelum } \\
\text { Pembelajaran }\end{array}$ & $\begin{array}{l}\text { Nilai Kemandirian } \\
\text { Pembelajaran }\end{array}$ & Selama \\
\hline Nilai Terendah & 58 & 74,67 \\
\hline Nilai Tertinggi & 80,67 & 88,67 \\
\hline Rata-rata Nilai & 71,90 & 80,83 \\
\hline Rata-rata Gain Score & & $\mathbf{0 , 3 0 7}$ \\
\hline Kategori Gain Score & Sedang \\
\hline \hline
\end{tabular}


Hasil penelitian menunjukkan bahwa kemandirian belajar siswa pada kelas kontrol dan eksperimen sama sebelum pembelajaran dalam program pengayaan dilakukan. Setelah dilakukan pembelajaran pada program pengayaan dengan menggunakan E-modul pengayaan isolasi dan karakterisasi bakteri pada kelas eksperimen dan tanpa menggunakan E-modul pengayaan pada kelas kontrol, ternyata kemandirian belajar siswa meningkat, dan pada kelas eksperimen, rata-rata kemandirian belajar siswa lebih tinggi daripada di kelas kontrol seperti yang dapat dilihat pada Gambar 1.

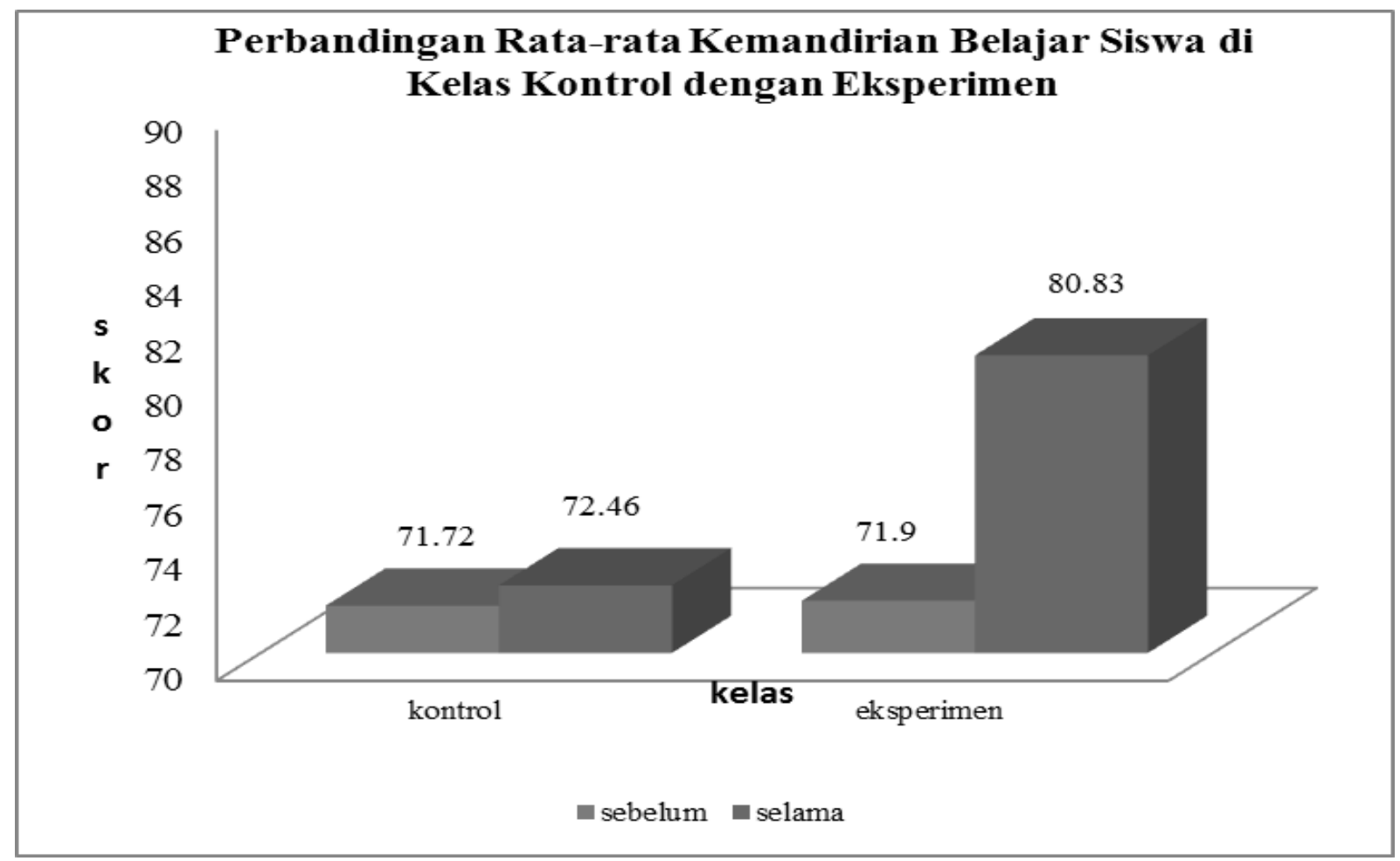

Gambar 1. Diagram Perbandingan Rata-rata Kemandirian Belajar Siswa

\section{PEMBAHASAN}

Pengembangan e-modul isolasi dan karakterisasi bakteri ini merupakan adaptasi dari hasil penelitian murni oleh Puput Saputri pada tahun 2018 mengenai "Isolasi, Seleksi, dan Karakterisasi Bakteri Asam Laktat (BAL) dari Intestinum Itik Manila (Cairina moschata) Sebagai Kandidat Probiotik" . Penelitian tersebut dapat dijadikan sumber belajar biologi pada program pengayaan untuk siswa SMA Kelas X MIPA. Agar dapat dijadikan sebagai sumber belajar, maka hasil penelitian ini dianalisis potensinya agar layak diangkat menjadi sumber belajar biologi. Menurut Suhardi (2008: 14-17), ada tiga tahapan yang harus dilakukan agar sebuah hasil penelitian dapat dijadikan sebagai sumber belajar di sekolah yaitu antara lain: (a) identifikasi proses dan produk penelitian, (b) seleksi dan modifikasi hasil penelitian sebagai 
sumber belajar biologi, (c) penerapan dan pengembangan hasil penelitian sebagai sumber belajar biologi.

Setelah dilakukan analisis, diketahui bahwa penggunaan E-modul pengayaan isolasi dan karakterisasi bakteri mendorong siswa menjadi lebih mandiri dalam belajar. Hal ini disebabkan karena sifat E-modul pengayaan itu sendiri yakni self instruction dan self contained yang memungkinkan siswa dapat belajar secara mandiri sesuai dengan gaya dan kecepatan belajar setiap siswa (Daryanto, 2013: 19).

Sifat self-instruction dalam e-modul menurut Winkel (2009: 472) dapat diartikan sebagai kemampuan siswa dalam membelajarkan dirinya sendiri, tidak tergantung pada pihak lain. E-modul bersifat self-instruction karena memuat tujuan pembelajaran yang jelas dan materi pembelajaran yang dikemas dalam unit yang spesifik (self-contained) sehingga mudah dipelajari.

Selain dari hasil analisis, berdasarkan observasi yang dilakukan oleh observer (para peer reviewer) juga mengungkapkan bahwa terjadi peningkatan kemandirian belajar di kelas eksperimen. Peningkatan tersebut terlihat pada aspek kemandirian belajar khususnya pada aspek inisiatif yakni dengan adanya beberapa siswa yang memberikan pertanyaan dan juga tanggapan dalam proses pembelajaran dengan menggunakan $e$-modul pengayaan.

Siswa mandiri memiliki keterampilan untuk mengakses dan memproses sumber-sumber belajar yang dibutuhkan untuk mencapai tujuannya. Yang (Sumarmo, 2004 : 12) memaparkan bahwa siswa yang memiliki kemandirian belajar yang tinggi cenderung belajar lebih baik dalam pengawasannya sendiri dari pada dalam pengawasan program; mampu memantau, mengevaluasi, dan mengatur belajarnya secara efektif; menghemat waktu dalam menyelesaikan tugasnya; dan mengatur belajar dan waktu secara efisien.

Jika belajar mandiri dan siswa mandiri dapat tercipta dalam proses pembelajaran, maka siswa tersebut akan memiliki kemandirian dalam belajar (Rahmah dkk, 2016: 75). Yamin (2008: 115) memaparkan bahwa kemandirian belajar adalah cara belajar aktif dan partisipatif untuk mengembangkan diri masing-masing individu yang tidak terkait dengan kehadiran guru, dosen, pertemuan tatap muka di kelas, dan kehadiran teman-teman di sekolah. Siswa akan memiliki kemandirian belajar apabila dalam proses pembelajaran siswa diberikan peluang untuk membuat keputusan sendiri terkait proses pembelajaran yang dilakukannya. Guru dapat mengembangkan kemandirian belajar siswa dalam proses pembelajaran dengan cara menjelaskan tujuan yang akan dicapai setelah mempelajari suatu materi serta keuntungan apa yang akan dimiliki jika siswa menguasai suatu kompetensi tertentu. Dimyati dan Mudjiono (2009: 39) menambahkan usaha guru untuk mendinamiskan berkaitan dengan kesiapan siswa 
menghadapi bahan belajar, penciptaan suasana belajar yang menyenangkan, mengoptimalisasikan media dan sumber belajar.

Perubahan sikap seperti peningkatan kemandirian belajar pada diri seorang siwa setelah pembelajaran disebabkan oleh beberapa faktor, salah satunya adalah motivasi. Cazan (2011: 112) mengungkapkan bahwa motivasi berhubungan dengan perkembangan kemandirian belajar seseorang, bahkan motivasi menjadi faktor yang mendasari proses kemandirian itu sendiri. Senada dengan Cazan, Zimmerman (Tillman dan Wiess, 2000) menyatakan bahwa anak yang mandiri yaitu anak yang mempunyai kepercayaan diri dan motivasi instrinsik yang tinggi. Dalam E-modul pengayaan ini juga telah berisi umpan balik yang dapat memotivasi siswa untuk meningkatkan kemandiriannya, namun akan lebih baik juga jika motivasi tersebut disampaikan oleh guru dan lingkungan belajar yang ada disekitar siswa seperti keluarga.

\section{KESIMPULAN DAN SARAN}

\section{Kesimpulan}

Berdasarkan tujuan dan hasil penelitian, dapat disimpulkan bahwa E-modul pengayaan isolasi dan karakterisasi bakteri yang dikembangkan berpengaruh secara signifikan terhadap kemandirian belajar siswa kelas X di SMA N 1 Jetis, Bantul yang dibuktikan dengan hasil analisis Independent Sample T Test dengan nilai signifikansi 0,000 $<0,005$ dan penghitungan $N$-Gain Score sebesar 0,307 dan termasuk dalam kategori peningkatan sedang.

\section{Saran}

Adapun saran yang dapat diberikan penulis guna pengembangan penelitian selanjutnya adalah sebaiknya turut diteliti pula pengaruh terhadap aspek motivasi dan minat belajar dengan penggunaan e-modul isolasi dan karakterisasi bakteri ini.

\section{DAFTAR RUJUKAN}

Burhanuddin; Nur Wahyuni, Esa. 2010. Teori Belajar dan Pembelajaran. Jogjakarta: Penerbit Ar-Ruzz Media.

Cazan, Ana Maria. 2011. Student Motivation And Self-Regulated Learning - A Theoretical Review. https://www.afahc.ro/ro/revista/Nr_2_2011/Articol_Cazan_nr2_2011.pdf

Daryanto. 2013. Menyusun Modul. Yogyakarta: Gava Media.

Depdiknas .2003. Undang-undang RI No.20 tahun 2003.tentang sistem pendidikan nasional. Dimyati dan Mudjiono. 2009. Belajar dan pembelajaran. Jakarta: PT. Rineka Cipta. 
Direktorat Pembinaan Sekolah Menengah Atas. (2017). Panduan Penilaian: Oleh Pendidik dan Satuan Pendidikan Sekolah Menengah Atas. Jakarta: Kemdikbud.

Hake, R. R. 1999. Analyzing Change/ Gain Score. Indiana: Indiana University.

Rahmah, Ari Isnaini, Sudiyanto dan Dini Octoria. (2016). Pengembangan Bahan Ajar Interaktif Untuk Meningkatkan Kemandirian Belajar Siswa Pada Pembelajaran Akuntansi. Jurnal "Tata Arta" UNS, Vol. 2, No. 1, hlm. 73-83.

Ratnaningsih, N. (2007). Pengaruh Pembelajaran Kontekstual terhadap Kemampuan Berpikir Kritis dan Kreatif Matematik serta Kemandirian Belajar Siswa Sekolah Menengah Atas. Disertasi. UPI Bandung : Tidak Dipublikasikan.

Saputri, Puput. (2018). Isolasi, Seleksi, dan Karakterisasi Bakteri Asam Laktat (BAL) dari Intestinum Itik Manila (Cairina Moschata) Sebagai Kandidat Probiotik. Skripsi.Yogyakarta: UNY.

Subali, Bambang. 2016. Prinsip Asesmen dan Evaluasi Pembelajaran.Edisi Kedua. Yogyakarta: UNY Press.

Suhardi. (2012). Pengembangan Sumber Belajar Biologi. Yogyakarta: Jurdik Biologi FMIPA UNY.

Sumarmo, Utari. 2004. Kemandirian Belajar: Apa, Mengapa, dan Bagaimana Dikembangkan pada Peserta Didik. [Online]. Tersedia: kemandirian-belaarmat-des-06-new.pdf.

Tilman, K.J dan Weiss, M. (2000). Self-Regulated Learning as Cross - Curriculer Competence (PISA). [Online]. Tersedia: http://www.pisa.no/pdf/turmoionste2004.pdf.

Winkel, W.S. (2009). Psikologi Pengajaran. Jakarta : Gramedia. 